\title{
PERKEMBANGAN LITERATUR HADIS DI INDONESIA ABAD DUA PULUH
}

\author{
Syaikh Abdillah \\ Dosen STAI Musadaddiyah Garut \\ Jl. Mayor syamsu No.2 Garut, Jawa Barat, Indonesa \\ E-Mail: Syaik_abdllah@gmail.com
}

\begin{abstract}
Search efforts in the hadith and hadith experts say Indonesia can be said not done systematically, not even adequate. It could be thought to be caused by several things. Firstly, the fact that the study of hadith moreover Hadith expert in Islamic studies is not as intense as others, such as al-Qur'an, fiqh, morals and so on. Second, the study of hadith can be said to be growing very slowly, especially when seen from the fact that the scholars Nusantara had written in tradition since the 17th century. However, as shown later, these writings are not developed further. Study hadith after it stagnated almost one and a half centuries. For this reason, the attention of the observer to the study of Hadith in Indonesia is still lacking. Even if there are observers who are concerned, attention is still partial and not comprehensive. This article will try to review the development of the study of Hadith in Indonesia in the twentieth century that belbatkan several works written by scholars of hadith or tradition can be said observers in the archipelago. Whether it works or original manuscripts speak Arabic and also there are some works that are adaptations of the work of other
\end{abstract}

Keywords: Development; Hadis; Indonesia; literature; Study.

\begin{abstract}
Abstrak
Upaya penelusuran hadis dan ahli hadis di Indonesiadapat dikatakan belum dilakukan secara sistematis, bahkan belum memadai. Hal ini bisa diduga disebabkan oleh beberapa hal. Pertama, kenyataan bahwa kajian hadis terlebih lagi ahli hadisnya tidak seintens kajian di keislaman yang lain, seperti al-Qur'an, fiqh, akhlak dan sebagainya. Kedua, kajian hadis bisa dikatakan berkembang sangat lambat, terutama bila di dari kenyataan bahwa para ulama Nusantara telah menulis di bidang hadis sejak abad ke-17. Namun demikian, seperti ter kemudian, tulisan-tulisan tersebut tidak dikembangkan lebih jauh. Kajian hadis setelah itu mengalami kemandekan hampir satu setengah abad lamanya. Untuk itulah, perhatian para pengamat terhadap kajian hadis di Indonesia masih sangat kurang. Kalaupun ada pengamat yang menaruh perhatian, perhatiannya masih parsial dan tidak komprehensif. Artikel ini akan mencoba mengulas perkembangan studi hadis di Indonesia pada abad ke duapuluh yang belbatkan beberapa karya yang ditulis oleh para ahli hadis atau bisa dikatakan pemerhati hadis di Nusantara. Baik itu karya-karya atau naskah asli berbahasa arab dan juga ada beberapa karya yang bersifat saduran terhadap karya lainnya.
\end{abstract}

Kata Kunci: Hadis; Indonesia; Kajian; Literature; Perkembangan.

\section{A. PENDAHULUAN}

Hadis adalah semua ucapan, perbuatan dan taqrir yang dinisbatkan kepada Rasulullah Saw ${ }^{1}$ Selain sebagai penjelas Alqur'an, Hadis juga berfungsi secara mandiri sebagai sumber hukum Islam yang kedua setelah Al-Qur'an (Qs. Al-Hasyr: 7), Oleh karena itu ketika Agama Islam memasuki wilayah Nusantara (yang menurut beberapa

\footnotetext{
${ }^{1}$ Subhi Shalih, Ulum Al-Hadits Wa Musthalahuhu (Beirut: Dar Al-Ilmu Li al-Malayin, 1988), 3.
}

sumber) pada abad ke-7 Masehi, ${ }^{2}$ otomatis ajaran tentang Hadis Rasulullahpun ikut dibawa serta oleh para penyebar Islam tersebut. Sebab tidak mungkin Islam akan menjadi agama yang mampu menuntun ke jalan hidup yang benar tanpa pemahaman terhadap Hadis-Hadis Rasulullah dan sunnahnya.

Memasuki abad ke-XVI dan seterusnya terjadi perkembangan atmosfir keilmuan Islam di Indonesia. Atmosfir ilmiah

\footnotetext{
${ }^{2}$ Azyumardi Azra, Jaringan Ulama Timur Tengah Dan Kebudayaan Nusantara Abad XVII \& XVIII (Bandung: Mizan, 1955), 25-27.
} 
keislaman ini tak dapat dipungkiri sebagai hasil dari suatu komunikasi yang intens antara ulama Indonesia dengan ulama yang ada di pusat keilmuan Islam, Hijaz (Mekah dan Madinah) dalam suatu jaringan Azyumardi Azra menamakan komunikasi tersebut dengan istilah "jaringan ulama". ${ }^{3}$ Dalam hal ini ada sejumlah ulama Indonesia yang punya kaitan erat dengan pusat Islam tersebut. ${ }^{4}$

Menurut penelitian Nurol Aen, pengembangan dan penyebaran Islam di Indonesia dilakukan secara kultural, antara lain melalui proses pendidikan Islam, seperti pengajian disurau, masjid atau madrasah, pesantren dan perguruan tinggi. Dengan berbagai keadaannya, ajaran Islam ini disampaikan dengan berbagai metode, di antaranya sorogan, wetonan, ceramah dan diskusi. $^{5}$

Lebih lanjut, mengenai sumber tulisan atau kitab yang digunakan dalam pengembangan Islam melalui jalur pendidikan ia mengatakan. ${ }^{6}$

"Menurut catatan. sejarah, pada mulanya, pengembangan Islam melalui jalur pendidikan ini menggunakan berbagai sumber tertulis, yaitu berupa berbagai kitab, khususnya yang berbahasa Arab. Dan dalam Perkembangan selanjutnya buku-buku yang berbahasa Arab tersebut diterjernahkan dan dihimpun oleh ilmuan muslim Indonesia ke dalam bahasa Indonesia dalam berbagai disiplin ilmu keislaman yang diterbitkan di beberapa kota hesar di indonesia".

Di antara sumber tulisan yang menjadi rujukan untuk menyebarkan Islam melalui jalur pendidikan adalah literatur Hadis, yang kedudukannya dianggap sangat urgen, sebab mencakup berbagai keilmuan Islam yang

3 Azra, 18.

4 Daud Rasyid Harun, merinci adanya 69 ulama Indonesia yang mempunyai kailan erat dendgan pusaat. keilmuan Islam di Hijaz. Daud Rasyid Harun, 'Juhud Ulama Lndonésia Fi Al-Hadits' (Universilas Darul Ulum), 12-17.

${ }^{5}$ Nurul Aen, 'Perkembangan Literatur Hadits Di Lndonesia', Majalah Istiqra, no.6.th. VI JuliDesember (1992), 7-22.

6 . Nurul Aen, 7-22. pokok, di antaranya adalah masalah aqidah, syari'ah dan akhlak. Dan pasti Islam akan kehilangan otoritasnya bila tanpa Hadis Rasulullullah Saw.

Tulisan ini akan mencoba untuk memaparkan perkembangan literatur Hadis, khususnya pada abad ke-20 (di Indonesia, yang dalam hal ini perlu diuraikan beberapa hal yaitu: Teori tentang masuk dan berkembangnya literatur Hadis di Indonesia, keberadaan literatur Hadis di indonesia abad ke-20, baik literatur mengenai ilmu dirayah Hadis, dan karakteristik literatur Hadis tersebut.

\section{B. PEMBAHASAN}

\section{Teori Tentang Masuk Dan Berkembangnya Literatur Hadis Di Indonesia}

Yang dimaksud dengan literatur Hadis dalam pembahasan ini adalah semua sumber tulisan yang berisi Hadis Rasulullah, baik berupa kitab atau buku yang memuat teksteks Hadis berbahasa Arab atau yang sudah ditambah dengan terjemahan Indonesianya juga termasuk literatur yang memuat Hadis yang berbentuk brosur atau majalah yang pernah terbit di Indonesia, dan juga termasuk sumber tulisan tentang ilmu dirayah al-Hadis.

Martin Van Bruinessen menyebutkan bahwa sebelum memasuki abad ke-20 belum ada kitab-kitab atau Iiteratur Hadis yang secara khusus dipelajari di lembaga pendidikan Islam di Nusantara ini, meskipun kitab-kitab klasik berbahasa Arab sudah dikenal dan sudah dipelajari pada abad ke-16, sebelum pesantren ada. ${ }^{7}$ Seorang peneliti kurikulum pesantren Jawa dan madura, L.W.C. Van den Berg, pada tahun 1886, tidak menyebutkan adanya Hadis sama sekali dalam kurikulum pesantren tersebut. ${ }^{8}$ ltu berarti bahwa sebelum memasuki abad ke20, secara khusus belum ada lembaga pendidikan Islam yang sudah memasukkan Hadis ke dalam kurikulum pendidikannya. Mengenai hasil penelitian Van den Berg ini, Martin Van Biuinessen mengemukakan: ${ }^{9}$

\footnotetext{
${ }^{7}$ Martin Van Bruinessen, Kitab Kuning, Pesantren Dan Tarekat (Bandung: Mizan, 1995), 27.

${ }^{8}$ Martin Van Bruinessen,161.

${ }^{9}$ Martin Van Bruinessen, 161.
} 
"Meskipun secara khusus belum ada Hadis yang dimasukkan ke dalam kurikulum pendidikan Islam saat itu, namun para santri telah menjumpai banyak Hadis selama mengikuti pelajaran, karena tidak ada karya fiqh dan akidah yang tidak didukung oleh argumen- argumen berdasarkan Hadis, hanya saja Hadis-Hadis itu telah diseleksi, diproses dan dikutip menurut keperluan pengarangnya".

Mengenai pengkajian kitab-kitab kumpulan Hadis, semisal al-kutub al-sittah ia mengatakan: ${ }^{10}$

"kitab-kitab kumpulan Hadis, baik enam kumpulan Hadis yang diakui (al-kutub alsittah) ataupun beberapa kompilasi populer seperti Masabih al-Sunnah, yang sangat terkenal di lndia tampaknya hampir tidak dipelajari di Nusantara seabad yang lalu. Mungkin perkecualian harus dinyatakan untuk beberapa kumpulan kecil Hadis, semacam Hadis Arba'in, kaiya al-Nawawi, karena beberapa ulama Indonesia sejak abad ke19 dan seterusnya telah mengumpulkan dan menerjemahkan kumpulan empat puluh Hadis tersebut".

Menurut dugaan penulis, kitab-kitab kumpulan besar Hadis (semisal al-kutub alsittah) itu sudah ada sebelum memasuki abad ke-20, meskipun tidak terdapat dalam kurikulum pendidikan Islam yang reguler, dan dalam jumlah yang sangat sedikit sekali, juga mungkin masih berupa tulisan tangan. Sebab menurut tradisi pesantren tradisional, kitab-kitab tersebut tidak dimasukkan kedalam kurikulumnya secara regular, kitabkitab itu hanya dipelajari secara khusus di hari pasaran (pada bulan Ramadhan), saat pesantren meliburkan program pendidikan reguler, dan membuka pasaran (pengkajian kitab) pada masyarakat umum untuk mengkaji kitab-kitab khusus semisal al-kutub al-sittah. Sampai sekarangpun sebagaimana yang penulis ketahui hanya beberapa pesantren saja yang secara resmi memasukkan kitab shahih Bukhari atau

\footnotetext{
${ }^{10}$ Martin Van Bruinessen, 161
}

shahih Muslim (dan al-kutub al-sittah lainnya) ke dalam kurikulum reguler.

Memasuki abad ke-20, perkembangan literatur Hadis di Indonesia mulai menunjukkan intensitasnya. Hal itu ditandai dengan didatangkannya sejumlah besar kitab kuning (termasuk diantaranya kitab-kitab Hadis) dari Timur Tengah oleh para ulama Indonesia, ${ }^{11}$ dan intensitas penekunan terhadap ilmu Hadis serta penerapan HadisHadis secara lebih intensif karena pengaruh pembaharuan yang sedang berhembus kencang di tanah air. ${ }^{12}$

Sejumlah sumber tulisan menyebutkan bahwa salah satu faktor pendorong pembaharuan (modernisme) yang terjadi di awal abad ke-20 adalah keinginan untuk kembali kepada ajaran Islam yang murni dengan merujuk kepada al-Quran dan Hadis, serta membuang jauh-jauh sikap taklid. ${ }^{13}$ Semangat modernisme ini dalam perkembangannya membawa perubahan yang sangat berarti dalam sistem pendidikan Islam di Indonesia, yaitu yang dipelopori oleh perkumpulan-perkumpulan Islam umuk membenahi pendidikan Islam dengan memperbaharui sistem, metode dan materi pendidikanya. Salah satu contohnya adalah yang dilakukan oleh perkumpulan Muhammadiyah. Paling tidak ada enam hal yang dimodernisir oleh Muhammadiyah dalam pendidikannya: Cara mengajar, bahan pelajaran, rencana pembelajarannya, pendidikan di luar waktu belajar, guru, dan pola hubungan guru dengan murid. ${ }^{14}$

Di antara lembaga-lembaga pendidikan Islam yang melakukan pembaharuan serupa adalah Madrasah Al-Irsyad (1913) Jakarta, ${ }^{15}$ Pesantren Sungayang Batusangkar (1897), ${ }^{16}$

\footnotetext{
${ }^{11}$ Martin Van Bruinessen,132.

${ }^{12}$ K.A Steen Brink, Pesantren, Madrasah Dan Sekolah: Pendidikan Islam Dalam Kurun Modern (Jakarta: LP3ES, 1926),166; Martin Van Bruinessen,

${ }^{13}$ L. Stoddard, Dunia Baru Islam (Jakarta, 1966),

14 Amir Hamzah W.S, Pembaharuan Pendidikan Islam (Malang: PT.ken Mutia, 1968), 120.

${ }^{15}$ Mahmud Yunus, Sejarah Pendidikan Islam Di Indonesia (Jakarta: Mutiara, 1995), 307-312.

${ }^{16}$ Mahmud Yunus, 142-143.
} 161. 305. 
Pondok modern gontor (1926), ${ }^{17}$ Perguruan Sumatra Thawalib (I921 ), ${ }^{18}$ Pesantren Persis Bandung (I936), ${ }^{19} \mathrm{dsb}$.

Dengan adanya perubahan tersebut, banyak materi-materi pelajaran baru yang dimasukkan dalam rencana pelajaran, yang dulunya tidak pernah tersentuh sama sekali, di antaranya adalah ilmu dirayah al-Hadis (ilmu yang membedakan Hadis palsu dengan Hadis autentik) dan ilmu umum. Dengan dimasukkannya ilmu dirayah al-Hadis ke dalam rencana pelajaran oleh lembaga pendidikan tersebut, merupakan langkah awal studi kritik tentang Hadis yang dilakukan di Indonesia melalui pendidikan Islam.

Studi tentang ilmu dirayah al-Hadis menjadi semakin semarak selelah adanya perguruan tinggi Islam di Indonesia, baik yang dikelola oleh negara atau oleh lembaga swasta, yang mengembangkan disiplin ilmu keislaman secara luas. terutama ilmu Hadis dengan sistem pembelajaran yang modern. Dalam hal ini seorang tokoh yang harus kita sebutkan adalah Prof. Dr. Hasbi AshShiddieqy. Dia bukan hanya mengenaikan system belajar Hadis secara modem di perguruan tinggi, ${ }^{20}$ tapi juga karya-karyanya yang monumental dalam bidang Hadis. Di antaranya adalah "Sejarah dan Pengantar Ilmu Hadis", "Koleksi Hadis-Hadis Hukum", yang terdiri dari sebelas jilid, memuat 1606 Hadis tentang hukum (fiqh), dan "2002 Mutiara Hadis" (I71 Hadis tentang aqidah, 1649 Hadis tentang fiqh, dan 182 Hadis tentang akhlak). ${ }^{21}$

Lain dari pada itu tuntutan terhadap penerapan Hadis-Hadis sacara lebih intensif dikalangan modernis juga mendorong mereka untuk menghimpun Hadis-Hadis yang menjustifikasi pandangan keagamaan mereka. Seperti Muhammadiyah umpamanya, mempunyai Himpunan putusan tarjih (1927-1972) yang berisi 534 Hadis. Demikian juga Ahmad Hasan dari Persatuan Islam (Persis) menerbitkan majalah Soal-

\footnotetext{
${ }^{17}$ Mahmud Yunus, 248-250.

${ }^{18}$ Mahmud Yunus, 73-75.

${ }^{19}$ Mahmud Yunus,299-301.

${ }^{20}$ Harun, 4.

${ }^{21}$ Nurul Aen, 7-22.
}

Jawab Hukum (1931-1934) yang memuat 1429 Hadis. $^{22}$ Hal ini menunjukkan bahwa gerakan puritanisme atau modernisme Islam mempunyai andil yang cukup besar dalam wacana perkembangan Hadis di Indonesia abad ke-20

Dari urnian diatas dapat difahami bahwa Prf. Dr. Hasbi Ash-Shiddieqy dan Ahmad Hassan adalah dua tokoh yang menurut penulis - mempunyai kontribusi sangat besar bagi perkembangan Hadis di Indonesia abad ke-20.

\section{Keberadaan Literatur Hadis di Indonesia Abad XX}

untuk mengetahui Iebih jauh tentang perkembangan Hadis di Indonsesia abad ke20, perlu menelusuri sejumlah literatur Hadis yang digunakan atau yang dikaji di lembagalembaga pendidikan Islam dan yang beredar di tanah air.

Mahmud Yunus, dalam bukunya, Sejarah Pendidikan Islam di Indonesia menyebutkan adanya sejumlah lembaga pendidikan Islam yang menjadikan Hadis dan ilmu dirayah al-Hadis sebagai mata pelajaran sejak masa-masa awal abad ke-20. ${ }^{23}$ Padahal hasil penelitian Van den Berg (1886), tidak menyebutkan Hadis sama sekali dalam, kurikulum pesantren di Jawa dan madura. Ini merupakan indikasi adanya perkembangan literature Hadis di Indonesia yang cukup berarti.

Dalam bukunya tersebut Mahmud yunus menyebutkan bahwa Hadis Arba'in dan Baiquni (ilmu dirayah al-Hadis) sudah dipelajari di Madrasah Sungayang Batusangkar sejak tahun 1897 M, di Madrasah Sumatra Thawalib sejak th. I921 M., di Madrasah Tarbiyah Islamiyah (Perti) sejak th.1928 M. ${ }^{24}$ Kitab Nail al-Authar dan Subul al-salam dipelajari di Al-Irsyad, Jakarta sejak th. 1913 M, ${ }^{25}$ Kitab Bulughulmaram, Shahihain dan Baiquni sudah dipelajari di Madrasah Mamba'alUlum, Surakarta, sejak th. I905M. ${ }^{26}$

\footnotetext{
${ }^{22}$ Nurul Aen, 7-22.

${ }^{23}$ Mahmud Yunus, 312, 143, 250, 75, 300.

${ }^{24}$ Mahmud Yunus, 143, 74, 100.

${ }^{25}$ Mahmud Yunus, 312.

${ }^{26}$ Mahmud Yunus, 287.
} 
Bulughulmaram dan Musthalah al-Hadis dipelajari di Pondok modem Gontor sejak. th. I926 M, dan di pesantren Persis sejak 1936 M. ${ }^{27}$ Kitab Shahih Bukhari dan Shahih Muslim dipelajari di madrasah Sumatra Thawalib sejak th. I921 M, dan di madrasah Tarbiyah Islamiyah (Perti) sejak I928 M. selain Hadis Arba'in. ${ }^{28}$

Hal ini diperkuat oleh Nurol Aen yang melakukan penelitian perkembangan Hadis secara khusus belakangan ini, ia menyebutkan sejumlah lembaga pendidikan islam telah menjadikan Hadis sebagai mata pelajarannya sejak dekade kedua abad ke-20 ini. $^{29}$

Bahkan hasil penelitian Martin Van Bruinessen menyebutkan 15 literatur Hadis yang berbeda-beda, yang dipelajari di 46 pesantren di Indonesia. ${ }^{30}$

\section{Literatur (Matan) Hadis}

Menurut penelitian Nurol Aen, sebelum kemerdekaan, literatur matan Hadis sangat terbatas. Hadis-Hadis terbitan dalam negeri dan terjemahannya telah dimuat dalam brosur dan majalah, namun belum ada yang diterbitkan daiam bentuk buku. ${ }^{31}$

Adapun brosur dan majalah yang banyak memuat matan Hadis adalah:
a) Himpunan
Putusan
Tarjih

Muhammadiyah (1929-1972). Himpunan ini memual 534 Hadis. (9 Hadis dalam masalah aqidah, 517 Hadis dalam masalah ibadah, dan 8 Hadis mengenai akhlak) ${ }^{32}$

b) Majalah soal Jawab (1931-1934), yang diterbitkan oleh A. Hasan dan pempinanpimpinan Persis Bandung. ${ }^{33}$

Dari laporan penelitian Martin Van Bruinessen di sejumlah Pondok pesantren di

${ }^{27}$ Mahmud Yunus, 251,301

${ }^{28}$ Mahmud Yunus, 74, 100.

${ }^{29}$ Nurul Aen, 7-22.

${ }^{30}$ Martin Van Bruinessen, 160.

${ }^{31}$ Nurul Aen, 7-22.

${ }^{32}$ PP. Muhammadiyah, Himpunan Putusan Tarjih I929 S/d 1972, ed. by 3 (Yogyakarta).

${ }^{33}$ Ahamad Hasan, Soal Jawab (Bandung: Cv. Diponegoro, 1983), Jilid I-III.
Indonesia tahun 1980-an menyebutkan 13 literatur matan Hadis yang di pelajari ialah: ${ }^{34}$

a) Bulugh al-Maram (Min Adillah alAhkam). Sebuah kumpulan yang dihimpun oleh lbnu Hajar al-Atsqalani (1449 M). Kitab ini telah diterjemahkan ke dalam bahasa Jawa (oleh Subki masyhadi Pekalongan), ke dalam bahasa Indonesia (oleh Bisri Musthafa Rembang dan A. Hasan Bangil).

b) Riyadh ash-Shalihin (Min Kalam Sayyid al-Mursalin), karya Yahya bin Syarif alDin al-Nawawi. Sebuah kumpulan Hadis tentang amal shaleh dan ibadah. Kitab ini diterjemah ke dalam bahasa Jawa oleh Asrosi Ahmad dan Akhmad Subki Masyhadi.

c) Shahih Bukhari.

d) Shahih muslim.

e) Subul al-Salam. Kitab karangan Muhammad Ibn 1sma'iI al-Kahlani (1769M), yaitu merupakan syarah terhadap Bulugh al-Maram.

f) al-Tajrid al-Sharih, karya Syihabuddin Ahmad al-Syarji al-Zabidi (1488 M). ini adalah salah satu kitab dari dua kitab seleksi yang popular terhadap Shahih Bukhari.

g) Jawahir al-Bukhari, karya Mushthafa M. Umarah. Yaitu kitab seleksi lain terhadap Shahih Bukhari.

h) Arbain al-Nawawi, karya Abu Zakariya Yahya al-Nawawi. Kitab ini banyak diajarkan di pesantren untuk para santri yang belum tinggi tingkatannya dan juga untuk perpustakaan keagamaan non kurikuler

i) Durrah al-Nasihin (Fi al-Wa'dz Wa alIrsyad) Merupakan himpunan Hadis karya Utsman Ibn Hasan al-Kubawi (1804 M).

j) Tanqih al-Qaul (al-Hadis Fi Syarh Lubab al-Hadis), karaya Muhammad Nawawi Ibn Umar al-Bantani. Ia merupakan kitab

\footnotetext{
${ }^{34}$ Martin Van Bruinessen, 161.
} 
syarh kumpulan Hadis al-Suyuthi, Lubab al Hadis.

k) Mukhtar al-AHadis, adalah sebuah kumpulan Hadis yang dihimpun oleh Akhmad hasyimi Bak, seorang pengarang Mesir modern.

1) Ushfuriyah. Disebut demikian dinisbatkan kepada nama pengarangnya, Muhammad Ibn Abu Bakar al-Usfuri. Yaitu kumpulan empat puluh Hadis yang populer, yang disertai dengan berbagai cerita teladan untuk setiap Hadis.

Selain beberapa kitab Hadis tersebut di atas, literatur (Matan) Hadis di Indonesia juga diperkaya dengan Hadisya buku-buku himpunan Hadis pilihan yang diambil dari berbagai kitab Hadis, yang disusun oleh orang-orang Indonesia. Beberapa literatur yang berbentuk himpunan itu ialah:

a) 2002 Mutiara Hadis.Buku ini terdiri dari tujuh jilid, di susun oleh T.M. Hasbi AshShiddieqy dari dua sumber kitab, Zad alMuslim, karya al-Syanqiethy, dan kitab al-lu'lu 'Wal al-Marjan. karya Muhammad Fuad Abd al-Baqi. Buku ini diterbitkan patama kali oleh Bulan Bintang pada tahun $1954 .{ }^{35}$

b) Koleksi Hadis-Hadis Hukum.Buku ini terdiri dari sebelas jilid, disusun oleh T.M. Hasbi Ash-Shiddieqy dari kitab Muntaqa al-Akhbar, karya Majd al-Din al-Harrani, kitab Bulugh al-Maram, karya Ibn Hajar al-Asqalani, dan kitab Umdah al-Ahkam, karya Abd al-Ghani al-Maqdisi. Buku ini diterbitkam peertama kali oleh P.T. AlMa'arif, Bandung 1966. ${ }^{36}$

c) Hadis Hadis Tentang Peradilan AgamaBuku susunan Fathurrahman ini

\footnotetext{
${ }^{35}$ Hasbi Ash-Shiddieqy, 2002 Mutiara Hadits (Jakarta: Bulan Bintang, 1975).

${ }^{36}$ Hasbi Ash-Shiddieqy, Koleksi Hadits-Hadits Hukum (Bandung: Darr al-Ma'rif, 1972).
}

memuat 94 Hadis tentang fiqh, dilerbitkan oleh Bulan Bintang, Jakarta tahun 1977. ${ }^{37}$

d) Mutiara Qur'an dan Hadis.Buku kumpulan Hadis karya Abdul Aziz Masyhuri ini mengandung dua mata pelajaran, al-Qur'an dan Hadis, yang disesuaikan dengan kurikulum tahun 1980. (Keputus Mentri Agama RI. No. 24 th. 1980) untuk Madrasah Tsanawiyah dan Madrasah Aliyah Dalam buku ini termuat 253 Hadis, 59 Hadis tentang aqidah, 87 Hadis tentang akhlak, dan 107 Hadis tentang fiqh. Buku ini diterbiitkan oleh Al-Ikhlas Surabaya 1982. ${ }^{38}$

e) Himpunan Hadis Shahih Bukhari. Sesuai dengan namanya, buku ini khusus memuat Hadis-Hadis yang diriwayaatkan oieh Bukhari, sebanyak 625 Hadis, 57 Hadis tentang aqidah, 26 Hadis tentang akhlak, dan 542 Hadis tentang fiqh. Buku ini disusun oleh Husein Bahriesy, dan diterbitkan oleh Al-Ikhlas Surabaya 1931. ${ }^{39}$

f) Jawahir al-Hadis. Buku ini disusun oleh Mawardi Muhammad, diterbitkan oleh Pustaka Sa'diyah Padang Panjang tahun 1950-an. Buku himpunan Hadis ini menjadi pegangan pelajar-pelajar di berbagai madrasah di Sumatra Barat, memuat 167 Hadis yang berkenaan dengan akhlak. ${ }^{40}$

g) Kumpulan Hadis Dha'if dan Palsu.Penyusunnya adalah A. yazid Qasim Koho, dan diterbitkan oleh Bina llmu, Surabaya,tanpa tahun terbit. Buku ini memuat 161 Hadis, 58 Hadis tentang

\footnotetext{
${ }^{37}$ Fathurohman, Hadits-Hadits Tentang Peradilan Agama (Jakarta: Bulan Bintang, 1977).

${ }^{38}$ Abdul Aziz Mashuri, Mutiara Qur 'an Dan Hadits (Surabaya: Pt. A1-Ikhlas, 19242).

${ }^{39}$ Husein Bahiesy, Himpunan Hadits Shahih Bukhar (Surabaya: PT. Al-Ikhlas, 1981).

${ }^{40}$ Nurul Aen, 7-22.
} 
aqidah, 22 Hadis tentang akhlak, dan 181 Hadis tentang fiqh. ${ }^{41}$

h) Pilihan Hadis politik, Ekonomi dan Sosial.Penulisnya adalah S. Ziyad Abbas, diterbitkan oleh Pustaka Panjimas, jakarta 1991. Buku ini memuat 337 Hadis, 218 Hadis tentang aturan sosial, 45 Hadis tentang politik, dan 74 Hadis tentang aturan ekonomi. ${ }^{42}$

Beberapa buku terjemahan Hadis, baik terjemahan dengan bahsa daerah atau bahasa Indonesia, juga melengkapi literatur Hadis yang berbahasa Arab di Indonesia. bukubuku tersebut antara lain ialah:

a) Terjemah al-Jami' al-Shahih, karya Iman Bukhari, oieh Zainuddin hamidi dkk Buku ini terdiri dari empat jilid, diterbitkan oleh penerbit Wijaya, Jakarta pada tahun 1957 1961, 1970, 1981 dan 1983. Memuat 1125 Hadis, 55 Hadis tentang aqidah, I012 Hadis tentang fiqh, dan 58 Hadis tentang akhlak.

b) Terjemah al-Jami' al-Shahih, karya Imam Muslim, oleh HA. Razak dkk. Sebanyak empat jilid, diterbitkan oleh penerbit Pustaka Al-Husna Iakarta. Dalam keempat jilid buku tersebut termuat 1503 Hadis, 233 Hadis tentang aqidah, 968 Hadis tentang fiqh dan 302 Hadis tentang akhlak.

c) Terjemah Bulugh al-Maram, karya Ibnu Hajar Al-Asqalani, oleh A. Hasan dan diterbitkan oleh CV. Diponegoro pertama kali tahun 1967. Kitab terjemahan ini memuat 1596 Hadis, I470 mengenai fiqh, 126 mengenai akhlak. Selain menterjemahkan, A. hasan juga menguraikan berbagai pendapat ulama tentang Hadis tersebut, dan pendapat dia sendiri.

${ }^{41}$ A. Yazid Kosim Koho, Kumpulan Hadits Da'if Dan Palsu (Surabaya: Bina Ilmu).

${ }^{42}$ S. Siyad Abbas, Pilihan Hadits Politik, Ekonomi Dan Sosia (Jakarta: Pustaka Panjimas, 1991). d) Terjemah al-AHadis al-Qudsiyah, susunan al-Majlis al-A'la Li al-Syu'un alIslamiyah, kairo. Kitab ini diterjemahkan oleh Drs. M. Zuhri ke dalam satu jilid, dan diterbitkan oleh penerbit Toha Putra Semarang tahun 1981. Buku ini memuat: 409 Hadis, 162 Hadis tentang aqidah, 11 Hadis tentang fiqh, dan 136 Hadis tentang akhlak.

e) Terjemah al-Lu'lu' Wa al-Marjan, karya Muhammad Fuad Abd al-Baqi, oleh $\mathrm{H}$. Salim Bahriesy menjadi dua jilid, dan diterbitkan oleh penerbit Bina Ilmu Surabaya tahun 1981. Buku terjemahan ini memuat 1906 Hadis, 167 Hadis tentang aqidah, 1541 Hadis tentang fiqh, dan 198 Hadis tentang akhlak.

f) Terjemahan Riyadh al-Shalihin, karya Imam Abu Zakariya lbn Syaraf alNawawi, oleh H. Salim Bahriesy ke dalam dua jilid, dan diterbitkan oleh penerbit AlMa'arif Bandung tahun 1983. Seluruh materi Hadis ini diterjemahkan dan disesuaikan dengansusunan teks aslinya. Buku ini memuat 1822 Hadis, 66 Hadis tentang fiqh, I756 Hadistentang akhlak .

g) Terjemahan Shahih Bukhari (dalam bahasa Sunda), oleh HMD. Ramli kedalam dua jilid, dilengkapi dengan terjemahan biografi dan metodologi yang ditempuh oleh Bukhari dalam pengumpulan Hadis shahih-nya.

h) Terjemahan Mukhtar al-AHadis, karya Sayyid Akhmad Hasyimi, oleh Muhammad Anwar dkk. Buku terjemahan ini diterbitkan oleh penerbit Sinar Baru Bandung 1983.

i) Terjemahan Mukhtashar Sunan Abu Dawud. karya al-Mundziri, Oleh H Bey Arifin dan A. Sinqithy Djamaluddin, Buku ini diterbitkan ke dalam dua jilid, oleh penerbit Asy Syifa' Semarang tahun 1992.

j) Terjemahan Sunan al-tirmidzi, karya imam Tirmidzi, oleh H. Muhammad Zuhri 
dkk. Buku ini diterbitkan dalam lima jilid, oleh penerbit Asy-Syifa' Semarang 1992

k) Terjemahan Muwatha' Imam malik, karya imam Malik, oleh Adib Bisri musthafa dkk. dalam dua jilid, dan diterbitkan oleh penerbit Asy-syifa' Semarang 1992.

1) Terjemahan Subul al-Salam, karya Muhammad Ibn Ismail al-Kahlani, oleh Abu BakarMuhammad. Buku ini diterbitkan oleh penerbit Al-Ikhlas Surabaya tanpa tahun dalamempat jilid.

m)Terjemahan Nail al-Athar, karya alSyawkani, oleh Abdul Qadir Hasan, Mu'amai Hamidi, Imron AM, dan Umar Fanany dalam enam jilid.

Dari penjelasan di atas dapat difahami bahwa penyebaran Hadis di Indonesia cukup beragam, dari yang berbentuk brosur, majalah, hingga bentuk buku baik berupa terjemahan ataupun himpunan Hadis-Hadis, dari yang palsu sampai yang autentik. Bahkan, dewasa ini penyebaran Hadis di Indonesia telah menggunakan teknologi komputer. itu bisa di dengan munculnya komputerisasi Hadis Shahih Bukhari, bersamaan dengan komputerisasi al-Qur'an itu sendiri. ${ }^{43}$

\section{Literatur Ilmu Dirayah al-Hadis}

Perkembangan ilmu dirayah al-Hadis di Indonesia, menurut Endang Soetari cukup bersaing antar buku-buku terjemahan dengan buku-buku yang ditulis oleh para cendikiawan muslim indonesia. Namun dia menyayangkan penyebaran buku-buku ini masih terbatas disekitar kampus atau lembaga-lembaga pendidik saja, tidak sebagaimana kitab-kitab (Matan) Hadis yang tersebar luas dikalangan masyarakat. ${ }^{44}$

Di antara buku-buku yang membahas ilmu dirayah al-Hadis yang dapat dikemukakan di sini adalah:

1. Baiquniyah, karya Thaha Ibn Muhammad al-Fattut al-Baiquni (I669

\footnotetext{
${ }^{43}$ Endang Soetari, Problematika Hadits (Bandung: Gunung Djati Press, 1997),57.

${ }^{44}$ Soetari, 57.
}

M). Berdasasrkan apa yang penulis ketahui, buku ini adalah yang paling awal dipakai di pesantren di Indonesia untuk santri kelas rendah.

2. Minhat al-Mughits, karya seorang ulama Al-Azhar, Hafidz Hasan Mas'udi.Sebagaimana kitab Baiquniyah, kitab ini juga yang paling awal dipelajari di pesantren di Indonesia, tapi untuk santri kelas atas.

3. Ilmu Musthalah al-Hadis, karya Mahmud Yunus. Buku ini banyak dipelajari diberbagai pesantren untuk santri kelas menengah atas.

4. Ulum al-Hadis wa Musthalahuhu, karya Subhi al-Shalih, diterbitkan oleh Darr alIlmi Lial-Malayin, Bairut, Libanon pertama kali taliun 1959.

5. Ma'rifat Ulum al-Hadis, karya Imam alHakim Abu Abdillah Muhammad Ibn Abdillahal-Hafidz al-Nisaburi, terbitan Bairut, Libanon.

6. Ushul al-Hadis, karya 'Ajaz al-Khatib, terbitan Bairut, Libanon.

7. Taisir Musthalah al-Hadis, karya Mahmud Thahhan, seorang pengajar Hadis di Fakultas Syari'ah dan Dirasah Islamiyah, Jami'ah Kuwait, diterbitkan oleh Syirkah Bungkul Indah, Surabaya.

8. Ikhtishar Musthalah at-Hadis, karya Fatchur Rohman, diterbitkan oleh penerbit Al-Ma'Arif, Bandung, dan pada tahun 1991, sudah mencapai cetakannya ke 7.

9. Sejarah dan Pengantar Ilmu Hadis, karya T.M. Hasbi Ash-Shiddieqy Buku ini pertamakali diterbitkan oleh Bulan Bintang tahun 1954, dan sampai tahun I993 ini telah mengalami cetak ulang ke 11 kali.

10. Status Hadis Sebagai Dasar Tasyri', karya Barmawi Umari, diterbitkan oleh AB Siti Syamsiyah, Solo, tahun 1965. 
11. Al-Hadis Sebagai Sumber Hukum, terjemahan dari buku al-Sunnah Wa makanatuhu FiTasyri' al-Islam, oleh penerbit Diponegoro, dan diterbitkan oleh penerbit tersebut tahun1979.

12. Ilmu Musthalah al-Hadis, karaya Abdul qadir Hasan, diterbitkan penerbit Bina Ilmu Surabaya, tahun 1979.

13. Kaedah-kaedah Keshahihan Hadis Ditinjau Darr Ilmu Sejarah, karya M. Syuhudi Ismail, diterbitkan oleh penerbit Bulan Bintang, Jakarta tahun 1988.

14. Membahas Ilmu-ilmu Hadis, terjemahan tim penerbit Pustaka Firdaus, Jakarta, dan diterbitkan oleh penerbit tersebut tahun 1993.

15. IImu Hadis, karya Endang Soetari, diterbitkan oleh penerbit Amal Bakti Press, Bandung tahun 1994.

16. Ulum al-Hadis, terjemahan Mujiyo dari buku Manhaj al-Nadq Fi Ulum al-Hadis, karyaNur al-Din Iter, diterbitkan oleh penerbit Rosdakarya, Bandung tahun 1994.

17. Ta'amulat Fi al-Shahihain, karya Murtadha Mutthahari. Sebuah buku yang menyoroti otentisitas sekian banyak Hadis yang terhimpun dalam Shahih Bukhari dan Muslim.

18. Hadis Dalam Persoalan, karya Muhammad Thalib, diterbitkan oleh penerbit AI-Ma'arif Bandung, 1978.

19. Hadis Nabawi dan Sejarah Kodifikasinya, terjemahan dari disertasi MM . Azmi yang berjudul Studies In Early Hadith Literature, oleh H. Ali Musthafia Ya'kub, diterbitkan oleh percetakan Pustaka Firdaus, Jakarta 1994,

20. Al-qur'an dan Hadis Dalam Sorotan Orientalis, karya Salimuddin A. Rahman, diterbitkan oleh penerbit Karya Kita, Bandung tahun 1987.
Tiga buku terakhir tersebut di atas adalah di antara buku-buku yang membahas pandangan orientalis terhadap Hadis Rasulullah Saw.

5. Karakteristik Literatur Hadis Di Indonesia Dari uraian tersebut di atas dapat diambil kesimpulan bahwa karakteristik literature Hadis di Indonesia adalah sebagaimana berikut:

1. Literatur Hadis yang beredar di Indonensia cukup beragam, ada yang berbentuk brosur, majalah, terjemahan dan himpunan, baik terbitan Timur Tengah ataupun terbitan dalam negeri sendiri Sebagian besar isinya memuat persoalan pokok agama, yaitu aqidah, fiqh dan akhlak.

2. Secara kuantitatif, dari sekian banyak literatur Hadis yang beredar, Hadis-Hadis tentang fiqh merupakan yang terbanyak, kemudian menyusui Hadis temang akhlak dan aqidah.

Literatur yang berkenaan dengan ilmu dirayah al-Hadis hanya beredar dilingkungan kampus atau atau di sekeliling lembagalembaga pendidikan saja, tidak menyebar luas di kalangan masyarakat seperti kitabkitab matan Hadis.

\section{SIMPULAN}

Berdasarkan uraian pembahasan di atas, dapat disimpulkan bahwa secara historis perkembangan literatur Hadis di Indonesia dipengaruhi adanya jaringan ulama Indonesia dan ulama di pusat keilmuan Islam, Mekah dan Madinah, yang terjadi sejak abad ke-16. Tapi yang tidak kalah pentingnya adalah pengaruh dari gerakan puritanisme dan modemisme Islam di Indonesia yang berhembus kencang di awal abad ke-20, yang kemudian di ikuti modernitas di bidang islam khususnya. Menurut hemat penulis, dua hal tersebut itulah yang mempengaruhi perkembangan Hadis (literatur Hadis) di indonesia di abad ke-20. 


\section{DAFTAR PUSTAKA}

Abdul Aziz Mashuri, Mutiara Qur 'an Dan Hadits (Surabaya: Pt. A1-Ikhlas, 19242)

Ahamad Hasan, Soal Jawab (Bandung: Cv. Diponegoro, 1983)

Amir Hamzah W.S, Pembaharuan Pendidikan Islam (Malang: PT.ken Mutia, 1968)

Azra, Azyumardi, Jaringan Ulama Timur Tengah Dan Kebudayaan Nusantara Abad XVII \& XVIII (Bandung: Mizan, 1955)

Bahiesy, Husein, Himpunan Hadits Shahih Bukhar (Surabaya: PT. Al-Ikhlas, 1981)

Fathurohman, Hadits-Hadits Tentang Peradilan Agama (Jakarta: Bulan Bintang, 1977)

Harun, Daud Rasyid, "Juhud Ulama Lndonésia Fi Al-Hadits" (Universilas Darul Ulum)

Hasbi Ash-Shiddieqy, 2002 Mutiara Hadits (Jakarta: Bulan Bintang, 1975)

- Koleksi Hadits-Hadits Hukum (Bandung: Darr al-Ma'rif, 1972)

Koho, A. Yazid Kosim, Kumpulan Hadits Da'if
Dan Palsu (Surabaya: Bina Ilmu)

Mahmud Yunus, Sejarah Pendidikan Islam Di Indonesia (Jakarta: Mutiara, 1995)

Martin Van Bruinessen, Kitab Kuning, Pesantren Dan Tarekat (Bandung: Mizan, 1995)

Nurul Aen, "Perkembangan Literatur Hadits Di Lndonesia," Majalah Istiqra, 6 (1992),7-22

PP. Muhammadiyah, Himpunan Putusan Tarjih 1929 S/d 1972, ed. by 3 (Yogyakarta)

S. Siyad Abbas, Pilihan Hadits Politik, Ekonomi Dan Sosia (Jakarta: Pustaka Panjimas, 1991)

Shalih, Subhi, Ulum Al-Hadits Wa Musthalahuhu (Beirut: Dar Al-Ilmu Li al-Malayin, 1988)

Soetari, Endang, Problematika Hadits (Bandung: Gunung Djati Press, 1997)

Steen Brink, K.A, Pesantren, Madrasah Dan Sekolah: Pendidikan Islam Dalam Kurun Modern (Jakarta: LP3ES, 1926)

Stoddard, L., Dunia Baru Islam (Jakarta, 1966) 